and the perimeter becomes

$$
2 x+\frac{2 h}{x}
$$

But since this is to be a minimum, we have

$$
C\left(2 x+\frac{2 h}{x}\right)=0, \text { whence } 2 C x-\frac{2 h C x}{x^{2}}=0
$$

Whence,

$$
2 x^{2}-2 h=0, \text { and } x=\sqrt{h}
$$

Again construct the rate-ratio

$$
C x \frac{\left(\frac{2 x^{2}-2 h}{x^{2}}\right)}{\frac{2 x^{2}+2 h}{x}}
$$

which is equal to

$$
\frac{C x\left(2 x^{2}-2 h\right)}{x\left(2 x^{2}+2 h\right)}
$$

Observation shows us that when $x$ becomes greater than $\sqrt{h,}$ the numerator and the denominator of this fraction will both be positive, and we therefore know that the value $x=\sqrt{h}$ is that which makes the function a minimum.

New York, March 13, I897.

\title{
CHEMICAL SECTION.
}

(Stated meeting, Tuesday, September 21, 1897.)

Dr. Lee K. Frankel, Vice-President, in the chair.

The UPPER SCHUYLKILL RIVER.

By Oscar C. S. Carter,

Professor of Geology and Mineralogy, Central High School, Philadelphia.

This river, which furnishes a water supply to Philadelphia and several towns along its banks, rises in the coal regions, in the northeastern part of Schuylkill County, Pa., nearly Ioo miles from Philadelphia. It flows southwest, then changes to. 
southeast, and then enters Berks County by a gap in the North Mountain at Port Clinton. It then flows southeast through the Great Limestone Valley and cuts through the South Mountain at the city of Reading. After leaving Berks County, it forms the boundary between Montgomery and Chester Counties, where it flows through the New Red Sandstone. It then enters the belt of older gneissic and micaceous rocks and flows southeast through Philadelphia County to the Delaware River.

Its general direction from the time it enters the gap in the North Mountain at Port Clinton until it enters the gap in the South Mountain at Reading is south Io $^{\circ}$ east; it then changes its course to south $50^{\circ}$ east, being deflected by the spurs of the South Mountain and by meeting the New Red Sandstone. It continues in this general direction to Philadelphia.

Elevation above Tide.-The general elevation of the Schuylkill and its tributaries at their source in the coal regions is about 800 feet higher than Philadelphia at the mouth of the river. In fact, the elevation of some of the towns near its source in Schuylkill County is over I,200 feet. Mahanoy City is $I, 240$ feet; Pottsville is $6 \mathrm{I} I$ feet, and Tamaqua, near the Little Schuylkill River, is 800 feet. These elevations are above mean tide at Philadelphia. The measurements given by the Schuylkill Navigation Company show that the fall of the river is as follows:

From Pottsville to Port Clinton, a distance of i 5 miles, the river descends 204 feet $=\mathrm{I} 4$ feet fall per mile.

From Port Clinton to Reading, a distance of 20 miles, the river descends 202 feet $=$ Io feet fall per mile.

From Reading to Norristown, a distance of $4 \mathrm{I}$ miles, the river descends $14 \mathrm{I}$ feet $=3^{\mathrm{I} / 2}$ feet per mile.

From Norristown to Philadelphia, a distance of I7 miles, the river descends $6 \mathrm{I}$ feet $=3 \% \mathrm{~T}$ feet fall per mile.

Acidity of the Schuylkill above Reading.-The Schuylkill River, above the city of Reading, is so strongly charged with sulphuric acid and sulphate of iron that it cannot be used as a water supply for Reading and the towns along its banks between Reading and the coal regions. We refer now to 
the Schuylkill, and do not include the Maiden and Tulpehocken Creeks, both of which empty into the river near Reading. Water of this kind would strongly corrode iron boilers, so that it cannot safely be used for the generation of steam. Its effect on the fauna of the Schuylkill is strongly marked. There are practically no fish in the river between Reading and Tamaqua, which is situated on the Little Schuylkill, or, more strictly speaking, between Maiden Creek, which is 8 miles above Reading and Tamaqua. A few suckers find their way above Reading as far as Maiden Creek, but above this no black bass, perch or chub are found. Molluscan life, which is provided with a protective shell of carbonate of lime, does not flourish in this acid water; their shells would be corroded and slowly dissolved. Mussels, water snails and cray fish find more congenial quarters in the Lower Schuylkill below Reading, where the water has lost its acidity.

It is well known that the acidity of the Schuylkill is due to impurities found in coal. Coal generally contains sulphur in two forms, as pyrite, or sulphide of iron $\left(\mathrm{FeS}_{2}\right)$, and sometimes as an organic compound of sulphur, which has not as yet been studied. When iron sulphide oxidizes on exposure to air, or water containing dissolved oxygen, it begins to disintegrate, and is finally converted into sulphuric acid and sulphate of iron, both of which are soluble in water. The pyrite is the principal source of sulphur in coal; in many specimens of coal and coaly slate, these glistening yellow specks are plainly visible. Every sample of coal analyzed contains some sulphur.

Acid Water from Collieries.-The following analyses were made by W. J. Williams, and show clearly the amount of free sulphuric acid and soluble sulphates that are found in water pumped from coal mines. The Lee Colliery is not on the Schuylkill Watershed. It is situated on the Susquehanna. Both of these waters, however, are typical mine waters of the Pennsylvania coal regions. The large amount of lime and magnesia sulphates in these waters is caused by the action of the free sulphuric acid on the rocks in and near the mines: 
READING COAI AND IRON COMPANY, WATER FROM FIIEN GOWAN COLIIERY.

Free sulphuric acid

Grains per

U. S. Gallon.

Iron and aluminum sulphates . . . . . . . . . . . I40'23

Calcium sulphate

Magnesium sulphate . . . . . . . . . . . . . $39^{\circ} 72$

Sodium chloride . . . . . . . . . . . . . . . $4^{6} 68$

Insoluble matter (principally coal dust) . . . . . . . . 5 $5^{\circ} \mathrm{O}$

Volatile and organic matter . . . . . . . . . . . 4300

Total solid matter . . . . . . . . . . . $\overline{29802}$

I,EE COAL COMPANY, SCRANTON, PA.

Grains per U. S. Gallon.

Free sulphuric acid

. 7.53

Iron sulphate . . . . . . . . . . . . . . . . . . 19'20

Calcium and magnesium sulphates . . . . . . . . . . 21 24

Sand . . . . . . . . . . . . . . . 2112

Volatile and organic matter . . . . . . . . . . . . 19\%or

Sodium chloride . . . . . . . . . . . . . . . Traces

Total solid matter.

$69^{*} 70$

The various tributaries of the Schuylkill River, in Schuylkill County, flow through the coal regions, and all the acid mine water which is pumped from the mines finds its way into the river. Years ago, before coal was mined in Pennsylvania, the river was free from acidity from its source to its mouth and fish were found along its entire course. It is stated that the amount of acid in the Big Schuylkill from Pottsville and beyond has been decreasing since I 868 , owing to the transfer of mining operations to the other side of the mountains, where the streams drain into the Susquehanna, and that the amount of sulphuric acid in the Big Schuylkill in 1885 was only onethird of what it formerly was. This is probably true, but the writer has never been able to find any analyses on record by which a comparison of the amount of acid in the Upper Schuylkill could be made. While a great number of analyses have been made of the water in the Lower Schuylkill, but few if any, complete analyses of the upper river are accessible. There seemed to be no necessity for such work, on account of its well-known unfitness for drinking purposes. The stream which furnishes the most sulphuric acid and sulphate of iron to Vol. CXLIV. No. 863 . 
the river is undoubtedly the Little Schuylkill. In the region of Tamaqua no fish can exist, and the stones in and along the river are colored brown from the precipitated iron in the form of ferric hydrate. On account of the decrease of acid in the Big Schuylkill beyond Pottsville a few hardy catfish have

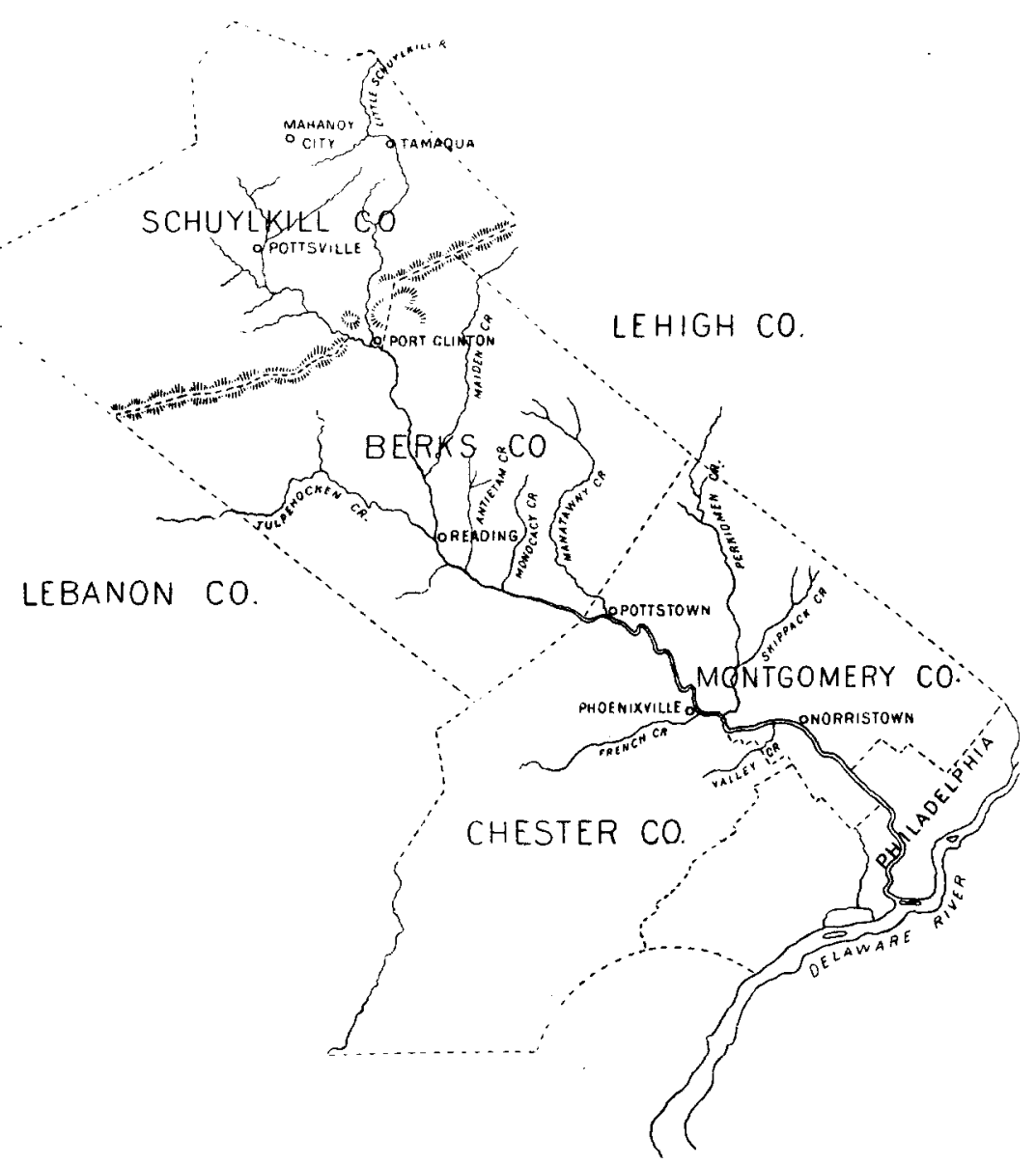

found their way up the river probably during some season of freshet when the water was strongly diluted and rendered comparatively fresh. A few of these fish are found between Port Clinton and Pottsville, but no others. These fish are not found in the river lower down between Port Clinton and 
Reading, because the Little Schuylkill discharges its acil waters into the river at Port Clinton.

How the Acidity is Destroyed.-Those unacquainted with the Schuylkill might suppose that this strongly acid water from the coal regions might reach Philadelphia and affect the water supply. Such, however, is not the case. Even the towns of Phœnixville and Pottstown are unaffected by it in the slightest degree. The water loses its acid character in the vicinity of Reading, and a short distance below that city the neutralization is complete. This is due to the fact that two important streams of hard water, the Maiden and Tulpehocken Creeks, flow through the limestone country and empty into the river near and at the city of Reading. The carbonate of lime, which they hold in solution completely, neutralizes the sulphuric acid and sulphate of iron in the water. In this double decomposition which takes place, two precipitates are thrown down, namely, sulphate of lime and carbonate of iron. The reaction is as follows:

$$
\begin{aligned}
& \mathrm{CaCO}_{3}+\mathrm{H}_{2} \mathrm{SO}_{4}=\mathrm{CaSO}_{4}+\mathrm{H}_{2} \mathrm{O}+{ }_{2} \mathrm{CO}_{2} \\
& \mathrm{CO}_{2} \\
& \mathrm{CaCO}_{3}+\mathrm{FeSO}_{4}=\mathrm{CaSO}_{4}+\mathrm{FeCO}_{3}+\mathrm{CO}_{2} . \\
& \mathrm{CO}_{2}
\end{aligned}
$$

The carbonate of iron being a very unstable salt, soon oxidizes to $\mathrm{Fe}_{2}(\mathrm{OH})_{6}$, ferric hydrate, and this brown stain of iron rust is often seen on the dam at Reading when the water is low. From the bridge at Reading, when the water is not muddy or turbid from coal dust, this white precipitate of sulphate of lime can clearly be seen.

The Tulpehocken and Wyamissing empty their limestone water into the river near this point, and the precipitated stilphate of lime renders the water almost milky in appearance, especially when an excess of acid water has been pumped from the mines. This salt of lime is slightly soluble in water, and a certain amount is dissolved. This accounts for most of the sulphate of lime in Schuylkill water, which analyses show is always present between Philadelphia and Reading. 
Limestone Streams Emptying into the Schuylkill.- The principal branches of the Schuylkill which flow through limestone districts and whose waters are more or less hard, are the Maiden, Tulpehocken, Wyamissing, Monocacy, Manatawny and Valley Creeks.

Maiden Creek is about 25 miles long. It rises in Lehigh County and flows over the formation known as Hudson River Shale and Utica Slate. It enters Berks County and flows over the same formation. It is fed from the slopes and foothills of the North Mountain. Finally, it reaches the Great Limestone Valley, through which it flows for a distance of 8 miles. Analysis shows that the temporary hardness is 7 , and that it contains 4.08 grains of carbonate of lime per gallon. Calculation shows that every million gallons of water that flows over the bed of Maiden Creek contains 57 I pounds of carbonate of lime in solution, which helps to neutralize the acidity of the main river. Then again, pebbles and particles of limestone dust, loosened by erosion, are carried by the current into the river and their action on the acid water is the same.

Tulpehocken Creek rises in Lebanon County and flows east through about 5 miles of the Great Limestone Valley. It enters Berks County and follows the limestone valley for another 5 miles, then leaves the valley and flows north and then east through the Hudson River Shale. It finally crosses the limestone valley again and empties into the Schuylkill at Reading. This creek flows through limestone for a distance of about I 5 miles. When the geology of the river is well understood, it will be interesting to know why the Tulpehocken did not take a short cut and follow the limestone valley along its entire course instead of flowing north through the Hudson River Shale. It seems to go out of its natural course. Perhaps all of the valley was not eroded sufficiently deep at that time.

Wyamissing Creek is a small creek which flows through about 3 miles of the Great Limestone Valley and empties into the river at Reading.

Monocacy' Creek is another small stream which flows 
through about 3 miles of limestone, and the rest of the way through shale and gneiss. It empties into the Schuylkill a short distance below Reading.

Manatawny Creek rises in the gneiss, and flows south through about 8 miles of limestone country; the rest of its course is through the New Red Sandstone. It empties into the river at Pottstown.

These are the limestone streams of the Upper Schuylkill, and were it not for them, the acid water would reach Philadelphia and affect our water supply. It is not likely that the limestone of the Plymouth and Chester Valleys, which crosses the river between Norristown and Conshohocken, would completely neutralize it, because the bed of the river is covered with mud. The Tulpehocken and Maiden Creeks furnish the greatest volume of limestone water and prevent the acid water from getting below Reading.

Fish Perish in 1882 .- In order to prove that the water supply of towns along the Lower Schuylkill would be affected if this acid water from the mines were not neutralized, it is only necessary to remember the summer of $\mathrm{I} 882$, when so many fish perished along the river. Between Reading and Pottstown hundreds of dead fish were observed floating in the river. Many were noticed as far south as Perkiomen Creek. The Philadelphia newspapers devoted columns to it, as it was feared the water supply of the city would be affected. The cause was due to the opening of several abandoned coal mines, and the excess of acid water was pumped into the river. This unusual supply was more than the limestone streams could neutralize during the low-water season, in consequence of which the acid water passed far below the city of Reading.

Water Supply of Reading.-On account of the acidity of the Schuylkill at Reading, that city has utilized Maiden and Antietam Creeks as a water supply. These creeks are not near the coal regions, and they furnish an abundant supply of water. The following analysis of the water of Maiden Creek, made by Prof. A. R. Leeds and furnished by the Mayor, will exhibit its purity: 


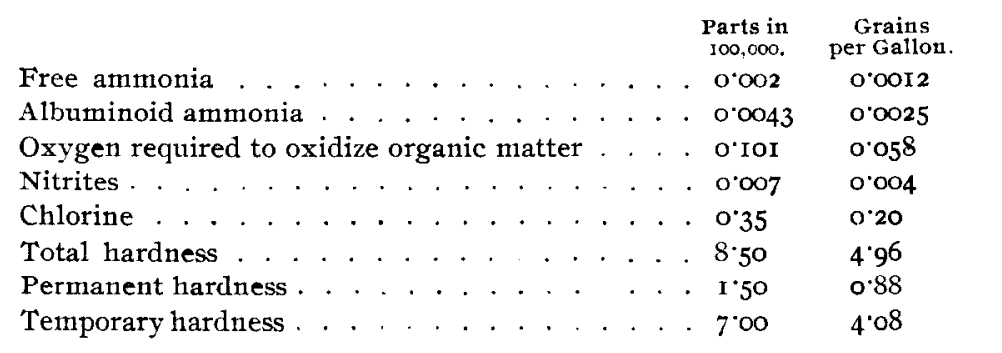

The report states that the quantities of free and albuminoid ammonia and nitrites are so small as not to need comment. They indicate but little drainage contamination. The water is somewhat hard, the temporary hardness being greater than the permanent hardness, which shows more carbonate than sulphate of lime. The hardness, in fact, is mainly due to the carbonate of lime.

Antictam Creck.-The other source of Reading's water supply is a mountain stream, which empties into the Schuylkill, about 4 miles below Reading. It is formed by the union of three mountain streams that have their origin in the high granitic or gneissic hills of Alsace Township. Water draining hills of gneiss is always soft. At the junction of these three mountain streams a reservoir was built, known as Antietam or Ohlinger Lake. The water is piped from the lake to Reading, a distance of about $3 \% / 4$ miles. There are also two large springs which flow directly into the pipes; they are known as Hampden and Edelman Springs. The water of Antietam I ake was analyzed in 1896 , by Prof. Leeds, with the following results:

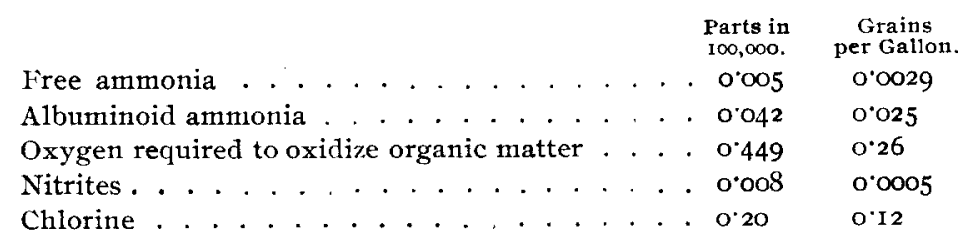

He states: "The albuminoid ammonia is ten times greater than that contained in the samples from Maiden Creek, and several times greater than is ever found in water of unquestionable purity. It amounts to the enormous figure of 0.042 
parts per 100,000, and points to the presence of much matter derived from the drainage of manurial and sewage material into the water of the lake."

Bacteriological Investigation.-Prof. Leeds' remarks and the analyses of Reading's water supply are interesting as well as instructive, and it may not be amiss to quote them, as they contain some facts of general interest.

"The first step was to count the entire number of colonies of bacteria of all kinds contained in each sample of water.

COLONIES OF BACTERIA PER CLBIC CENTIMETER.

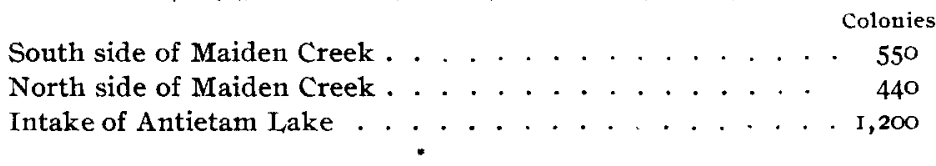

"These figures tell us the number of bacteria, but nothing as to their nature, nor do they conclusively point to the presence of dangerous contamination. But it may be said that, as a general rule, surface waters which are entirely satisfactory contain from about 50 to 200 colonies of bacteria per cubic centimeter. When examined in March, I894, the sample from Maiden Creek contained 50 colonies. At this present date, I 896 , both samples contain a larger number of bacteria from Maiden Creek than was expected, judging from the results in I894 and from the analysis of the water; but later on I shall show that these large numbers have not the damaging significance as at the first glance they appear to have. The mere counting of the relative numbers of bacteria in equal volumes of the water is a simple task compared with that of determining the species to which these multitudes of bacteria belong, and whether any of these species belong to the diseaseproducing varieties, the so-called pathogenic bacteria.

"In the present instance I was more especially charged to look for and report upon the presence or absence of the bacillus of typhoid fever in each of the four waters. To ascertain these facts a large number of cultures and hundreds of microscopic examinations, prosecuted without cessation and extending over the past interval of ten days, had to be made. The sample from the north side of Maiden Creek contained 
the fewest species. They belonged almost entirely to the kinds of bacteria which are always found in natural running waters. When water comes from very deep wells, it should contain very few or no bacteria, since these will have been filtered out by the subsoil before the water has found its way into the subterranean reservoir. But when water passes over the surface of the ground, it always takes up some organic matter and along with it some bacteria. These ordinary water bacteria in this case are essential and beneficial, because their work is to assist in the oxidation of the organic matter, and in this manner to purify the water. This was the work the species found in the water taken from the north side of Maiden Creek were doing, and although their number was large, I do not consider their presence prejudicial to the purity of this water. There were no pathogenic bacteria in samples taken from both the north and south sides of the creek, and I consider the supply from this source safe. The case is entirely different with the Antietam Lake and the faucet water. In both, but more especially the former, the bacteria belonging to species which are associated with decaying animal matters were those chiefly found. Most diligent search was made in both waters for the specific bacillus of typhoid fever (the bacillus typhi abdominalis or the bacillus of Eberth-Gaffky), which permeates the intestines and other organs of a typhoid patient, and after leaving the human body is capable of living a considerable time in the water contaminated by the voidings of the invalid. But this specific bacillus was not present in the two samples submitted to me. There were other bacilli present which are almost always associated with the typhoid bacillus, and which have, indeed, been called pseudo-typhoid bacilli, and it has been held by some eminent authorities that when these latter find their way into the alimentary tract, they take on increased virulence under favorable conditions and develop into the true bacillus of typhoid. However that may be, 1 consider the number and kinds of bacteria found in the Antietam Lake and faucet waters, more especially in connection with the corresponding evidence of the chemical analyses, sufficient to indicate that these waters were dangerously con- 
taminated with bacteria capable of producing disease. In the light of the chemical and bacteriological investigations it was recommended that the work of excluding from the drainage area of Antietam Lake all matters of a sewage nature by means of condemnation and purchase of offending properties when necessary, or prohibition wherever mere prohibition would be effectual, should be pushed with great energy. The rights of the municipality in defending the purity of its water supply are paramount, and the legal remedies are adequate to meet every exigency." These recommendations were afterward carried out by the city and the source of contamination done away with and properties purchased.

Maiden Creek Pumping Station.-At this station they use two Worthington pumps, one 5,000,000 gallons and the other and newer 10,000,000 gallons. The water is pumped directly from the creek, 8 miles above Reading, and carried south to Hampden District reservoir, through II,687 feet of 30-inch pipe and 22,105 feet of 24-inch pipe, against a static head of 208 feet. While it is possible to force I0,000,000 gallons daily through this main, it is considered safer to force $8,000,000$ gallons.

STORAGE CAPACITY OF RESERVOIRS.

Gallons.

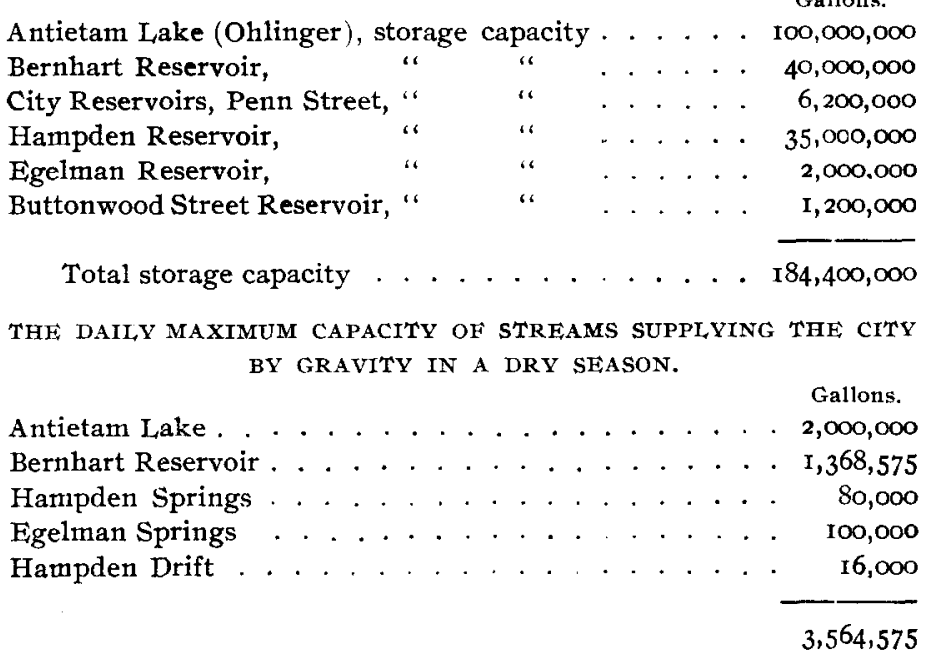

The daily per capita consumption is about I 20 gallons. 
Water Supply of Touns below Reading.-The towns between Reading and Philadelphia obtain their water supply from the Schuylkill River. Pottstown formerly pumped from the river below the town, and thus received some surface drainage from the town. This was afterward changed, and the supply is now drawn from above the town. The reservoir is about I mile from the river, and has a capacity of $6,000,000$ gallons. They have a pump that furnishes 4,500,000 gallons in twentyfour hours. Norristown also obtains a supply from the Schuylkill. There is an island in the river at that point over a mile in length, which divides the river in two parts. The water pipes run under the river and also the island, so that the supply is drawn from the other side of the island, thus avoiding the contamination of Stony Creek, which contains the drainage of the State Insane Asylum. The capacity of the reservoir is I I,000,000 gallons. They have two pumps, a Worthington, which supplies 5,000,000, and a Newbold, which supplies 2,500,000 gallons. The water between Reading and Norristown, a distance of $4 \mathrm{I}$ miles, is good as a general rule, because there are few towns between these points; the only two of considerable size are Pottstown and Phœnixville. The amount of drainage that gets into the river between these points can, to a certain extent, be regulated. Between Norristown and Philadelphia, as is well known, the water is not so pure, on account of drainage. It is not necessary to enlarge on this point, as the Lower Schuylkill has been well studied and many analyses have been made.

Fish of the Schuylkill.-The fish commissioners tell us that thirty-three years ago therewere no black bass in Pennsylvania. At Harper's Ferry, on the Potomac, were purchased $45^{\circ}$ fullsized adult hass; these were deposited in the Delaware near Easton. The writer remembers in 1870 , when black bass were first introduced into the Schuylkill; in a few years they became quite abundant and of some importance as a food supply. At that time the red fin, roach and chub were abundant in the river, and the so-called dogfish was common. Many fishermen and some of the fish commissioners have informed me that the red fin is now extinct and the roach and chub 
are disappearing. The black bass feed on them. There are many German carp in parts of the Perkiomen and Skippack Creeks; in some places they keep the dams muddy. Among Americans this fish is not regarded with much favor, although it is a favorite food fish in Bohemia. The Delaware, at Trenton, is full of large carp. Near Burlington the carp fisheries furnish Philadelphia and Trenton with nearly a ton of carp per week, consumed mostly by foreigners. The black bass are decreasing in the Schtrylkill, owing to the fact that the carp eat their spawn, and also to the fact that the culm or coal dust which comes from the coal region annoys them, as they do not thrive on muddy bottoms. Often after a heavy rain in the coal regions Philadelphia water will be dirty for a week. The greatest amount comes from the Little Schuylkill, although much is dumped along the Big Schuylkill. There was some coal dust dumped along the west side of the Schuylkill between Norristown and Philadelphia which the high water and heavy rains would stir up, but this practice has been stopped.

DR. Joseph W. Richards, President, in the chair.

SOME NEW DERIVATIVES OF DIACETYL.

By Harry F. Keller and Philip MaAs.

Since communicating the restlts obtained in studying the action of oxidizing agents upon diacetyl, we have continued our work on this diketone in several directions.

The ready and quantitative conversion of diacetyl into acetic acid by certain oxidizing agents, notably hydrogen peroxide, induced us to try whether the halogen-substituted products, dibromo-diacetyl and tetrabromo-diacetyl, would behave in an analogous manner. If they, respectively, yielded bromacetic acid and dibromacetic acid, their symmetrical structure might be regarded as definitely established. Thus: 